\title{
Reproducibility and intraindividual variation over days in buccal cell DNA methylation of two asthma genes, interferon $\gamma$ (IFN $\gamma$ ) and inducible nitric oxide synthase (iNOS)
}

\author{
DZ Torrone ${ }^{1}$, JS Kuriakose ${ }^{1}$, K Moors $^{1}, \mathrm{H}_{\text {Jiang }}{ }^{1}$, MM Niedzwiecki ${ }^{2}$, FF Perera ${ }^{2}$ and RL Miller ${ }^{1,2,3^{*}}$
}

\begin{abstract}
The biological mechanisms responsible for the onset and exacerbation of asthma symptoms in children may involve the epigenetic regulation of inflammatory genes after environmental exposures. Using buccal cells, we hypothesized that DNA methylation in promoter regions of two asthma genes, inducible nitric oxide synthase (iNOS) and interferon $\gamma$ (IFNy), can vary over several days. Repeat buccal samples were collected 4 to 7 days apart from 34 children participating in the Columbia Center for Children's Environmental Health (CCCEH) birth cohort study. Several field duplicates (sequential collection of two samples in the field) and replicates (one sample pyrosequenced twice) also were collected to ensure consistency with collection and laboratory procedures. DNA methylation was assessed by pyrosequencing a PCR of bisulfite-treated DNA. We found that replicate and field duplicate samples were correlated strongly $(r=0.86$ to $0.99, P<0.05)$, while repeat samples demonstrated low within-subject correlations ( $r=0.19$ to $0.56, P=0.06$ to 0.30 ). Our data reveal DNA methylation as a dynamic epigenetic mechanism that can be accessed safely and reproducibly in an inner city pediatric cohort using noninvasive buccal swabs and pyrosequencing technology.
\end{abstract}

Keywords: methylation, asthma, IFNy, iNOS, buccal mucosa, epigenetic regulation, pediatric, inner city

\section{Introduction}

The biological mechanisms responsible for the development of asthma symptoms in children following acute exposure to air pollution and other triggers are complex. These include the induction of oxidative stress pathways and formation of excessive reactive oxygen species in the airways [1-5]. Also, exposure to diesel and other combustion products may upregulate proallergic $\mathrm{T}$ helper (Th) 2 immune mechanisms [1,6-9]. Epigenetic regulation of gene expression associated with airway inflammation and allergic immune responses following exposure to air pollutants has been proposed as a key molecular step linking environmental exposures with

\footnotetext{
* Correspondence: rlm14@columbia.edu

'Division of Pulmonary, Allergy and Critical Care of Medicine, PH8E, Columbia University Medical Center, 630 West 168th Street, New York, NY 10032, USA

Full list of author information is available at the end of the article
}

altered asthma gene expression and asthma symptoms [10-14].

To date, clinical research on epigenetic changes in asthma and other complex diseases has been limited, especially in children [11,12]. One cross-sectional study by White and colleagues observed promoter demethylation of the allergy counter-regulatory and Th1 cytokine interferon $\gamma$ (IFN $\gamma$ ) gene in association with in vitro differentiation of CD4+ neonatal T cells [15]. Another study by Kwon and colleagues found phytohemagglutinin (PHA) and dust mite allergen stimulation of CD4+ $\mathrm{T}$ lymphocytes induced small increases in the degree of demethylation in several CpG loci of the Th2 interleukin (IL)-4 promoter $\left(\mathrm{CpG}^{-80}, \mathrm{CpG}^{+5}\right)$ in adult asthmatic subjects, when compared to the control group [16]. The changes in DNA methylation at the IFN $\gamma$ promoter were less consistent. Recently, Breton and colleagues sampled children living in Southern California in one of the first large cohort studies analyzing DNA methylation of 
asthma genes in buccal cells [17]. They hypothesized that buccal cell DNA methylation levels in two genes important to the production of proinflammatory nitric oxide, namely arginase (ARG) and inducible nitric oxide synthases (iNOS), would be associated inversely with fractional exhaled nitric oxide (FeNO) levels measured concurrently at one timepoint. They found that methylation levels in the promoter regions of ARG1 and ARG2, but not iNOS, were associated inversely with FeNO levels among asthmatic children.

Despite these few advances, several fundamental questions still need to be elucidated in environmental epigenetic asthma research. Some relate to basic questions about quality assurance and controls, such as the reproducibility of biospecimen collected under 'real world' field conditions and their quantification of DNA methylation levels in the laboratory. Another is whether biologically relevant epigenetic marks change readily over time, even over the short term. Our objective was to answer such fundamental questions in a pediatric urban cohort using non-invasive duplicate and repeat sampling. Our approach was to collect duplicate and repeated buccal cells, collected as self-performed cheek swabs by children in the field (that is, the child's home), as an accessible population of aerodigestive tract cells that may undergo changes in gene expression following exposure to environmental toxicants (for example, environmental tobacco smoke (ETS)) in a manner that correlate with those derived from the airway [18-20]. Also, as described above, buccal cells demonstrate gene-specific DNA demethylation that has been associated with airway inflammation [17].

We also chose to measure DNA methylation of two representative asthma genes, namely IFN $\gamma$ and iNOS. IFN $\gamma$ is a well established negative regulator of airway allergic immune responses [21]. The induction of IFN $\gamma$ primarily is regulated by demethylation of CpG sites within the IFN $\gamma$ gene $[5,15,22]$. While Breton and colleagues did not find associations with iNOS demethylation in buccal DNA and FeNO production, Tarantini and colleagues found that fine particulate matter exposure over days was associated with iNOS demethylation in peripheral blood mononuclear cells (PBMCs) [23]. Our aims were (1) to determine the reproducibility of levels of DNA methylation at multiple CpG sites for both genes when collected as duplicate samples in the field, and (2) to determine whether changes in DNA methylation levels occur over days.

\section{Methods}

\section{Collection of buccal cell DNA samples}

Buccal samples were collected using the Cytosoft Cytology Brush in Qiagen's Puregene Buccal Cell Core Kit (Qiagen Sciences, Germantown, MD, USA) from 34 children aged 9 to 10 years old living in Northern Manhattan and the Bronx, NY, USA, participating in the Columbia Center for Children's Environmental Health birth cohort study $[1,24,25]$. Informed consent and assent were obtained from all participants prior to their participation in the study. Field technicians traveled to the subject's home and instructed children not to eat or drink for $1 \mathrm{~h}$ prior to cheek swab. Each child rinsed his/ her mouth with water and then brushed the inside of his/her cheek for 1 minute. Upon completion, the field technician placed the swab immediately into $600 \mu \mathrm{l}$ of cell lysis solution (Qiagen). For field duplicate samples, the children were given two swabs to brush inside their cheeks in immediate succession for 1 minute each.

\section{Extraction, quantification, and bisulfite conversion}

Buccal cell DNA extractions were performed using Puregene Buccal Cell Core Kits (Qiagen) according to the manufacturer's instructions, except all centrifugations were conducted at $4^{\circ} \mathrm{C}$ instead of room temperature. Buccal DNA was quantified using PicoGreen (Invitrogen Corporation, Carlsbad, CA, USA) ultrasensitive fluorescent nucleic acid stain for double-stranded DNA. Bisulfite conversion was performed on $200 \mathrm{ng}$ of genomic buccal cell DNA using Zymo Research's EZ DNA Methylation Kit (Irvine, CA, USA) and the manufacturer's instructions, with one modification. Samples were incubated under the Alternative Incubation Conditions for Illumina Infinium Methylation Assay with an increased number of cycles $\left(20\right.$ cycles of $95^{\circ} \mathrm{C}$ for $30 \mathrm{~s}$ and $50^{\circ} \mathrm{C}$ for $15 \mathrm{~min}$ ) according to the manufacturer's instructions.

\section{PCR amplification and pyrosequencing}

The primers for performing PCR and the PCR product sequencing (Table 1) were designed using PyroMark Assay Design 2.0 software (Qiagen, Valencia, CA) for the regions of interest for IFN $\gamma$ and iNOS (Figure 1).

\section{Table 1 Primer sequences}

\begin{tabular}{|c|c|c|}
\hline Gene & Primer & Sequence \\
\hline \multirow[t]{4}{*}{$\mathrm{IFN} \gamma$} & Forward & 5'-AGAATGGTATAGGTGGGTATAATGG-3' \\
\hline & Reverse & $\begin{array}{l}\text { 5'-Biotin- } \\
\text { CAAAACAATATACTACACCTCCTCTA-3' }\end{array}$ \\
\hline & $\begin{array}{l}\text { Sequencing }\left(\mathrm{CpG}^{-}\right. \\
\left.{ }^{-}\right)^{\mathrm{a}}\end{array}$ & 5'-ATTATПTATTTAAAAAAATTGTG-3' \\
\hline & $\begin{array}{l}\text { Sequencing }\left(\mathrm{CpG}^{-}\right. \\
\left.{ }_{186}\right)^{\mathrm{a}}\end{array}$ & 5'-GGTGGGTATAATGGGTTTG-3' \\
\hline \multirow[t]{3}{*}{ iNOS } & Forward & 5'-TTAGGGTTAGGTAAAGGTATITTGTा-3' \\
\hline & Reverse & $\begin{array}{l}\text { 5'-Biotin- } \\
\text { CAATTCTATAAAACCACCTAATAATCTTAA-3' }\end{array}$ \\
\hline & Sequencing ${ }^{\mathrm{b}}$ & 5'-TAAAGGTATIITTGTITAA-3' \\
\hline
\end{tabular}

${ }^{\mathrm{a}}$ Site based on previous studies of interferon (IFN $\gamma$ ) [15].

${ }^{\mathrm{b}}$ Site based on previous studies of inducible nitric oxide synthase (iNOS) $[17,23]$. 


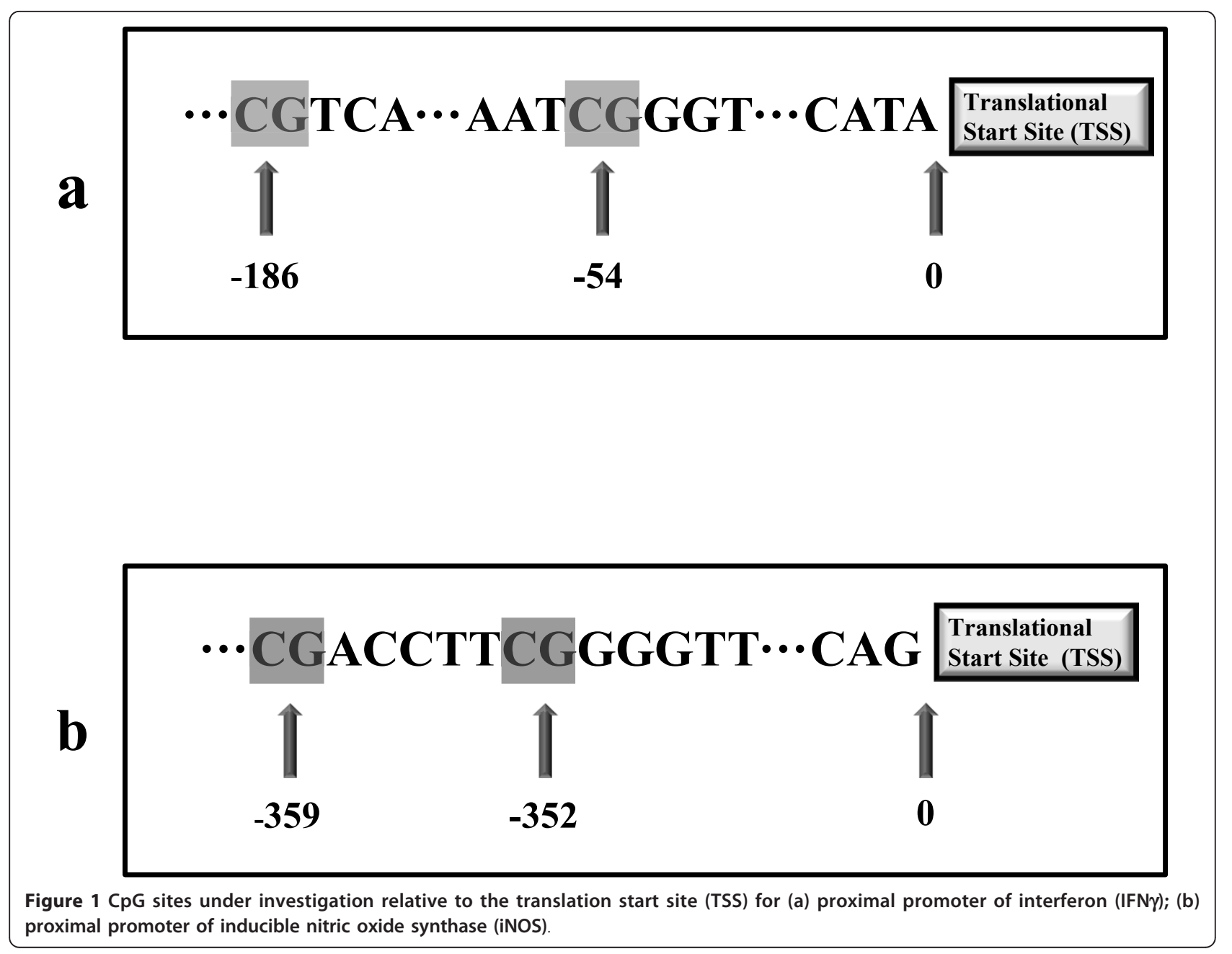

These targeted areas were chosen based on previous evidence of epigenetic regulation following inhaled environmental exposures [13,23]. PCR reactions were performed with Qiagen HotStarTaq DNA polymerase reagents for IFN $\gamma$ and iNOS with the following concentrations for each ingredient in the PCR mixtures: $1 \times$ PCR buffer, $1.5 \mu \mathrm{M}$ of $\mathrm{MgCl}_{2}, 0.2 \mu \mathrm{M}$ dNTP, $0.4 \mu \mathrm{M}$ forward primer, $0.4 \mu \mathrm{M}$ reverse primer. The PCR programs for the IFN $\gamma$ thermocycler were: $15 \mathrm{~min}$ hot start at $95^{\circ} \mathrm{C}$, followed by 50 cycles of $95^{\circ} \mathrm{C}$ for $30 \mathrm{~s}, 55^{\circ} \mathrm{C}$ for $1 \mathrm{~min}$, and $72^{\circ} \mathrm{C}$ for $1 \mathrm{~min}$, with a $10 \mathrm{~min}$ elongation at $72^{\circ} \mathrm{C}$. The PCR programs for the iNOS thermocycler were: $15 \mathrm{~min}$ hot start at $95^{\circ} \mathrm{C}$, followed by 50 cycles of $95^{\circ} \mathrm{C}$ for $30 \mathrm{~s}, 56^{\circ} \mathrm{C}$ for $1 \mathrm{~min}$, and $72^{\circ} \mathrm{C}$ for $1 \mathrm{~min} 30 \mathrm{~s}$, with a 10 min elongation at $72^{\circ} \mathrm{C}$. The PCR product was sequenced using PyroMark Q24 Pyrosequencer after verifying the positive PCR products by visualizing the appropriately sized band on a $1.2 \%$ agarose gel. All DNA extractions and bisulfite conversions were performed by the same lab researcher (DZT) who also performed all the IFN $\gamma$ pyrosequencing. All iNOS pyrosequencing was performed by a second researcher (JSK).

\section{Statistical analysis}

Concordance correlations were calculated for all replicate (amplified and sequenced more than one time) and field duplicate (sequential collection of two samples in the field) samples. Within subject correlations were calculated for samples repeated 4 to 7 days later in the same children. For repeat samples, within subject correlations were assessed using SPSS (SPSS, Chicago, Il, USA). Each CpG site was analyzed separately.

\section{Results}

In order to determine whether experimental procedures for PCR and pyrosequencing produced repeatable and consistent data, replicate samples were run. We found that replicate samples were highly correlated for IFN $\gamma$ and iNOS at all CpG sites tested (Figure 2). For example, the concordance correlations (rho) between the first and second pyrosequencing run for the replicate IFN $\gamma$ 
$\mathbf{a}$

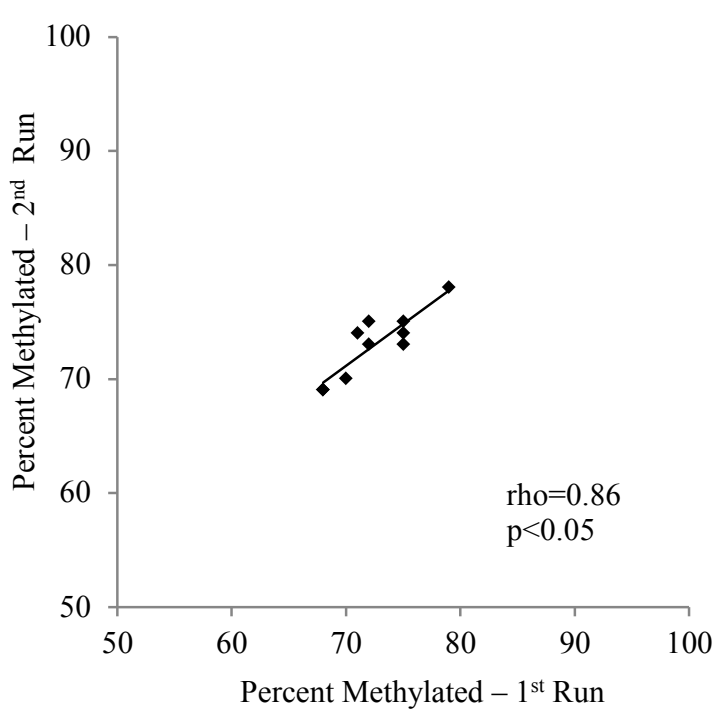

b

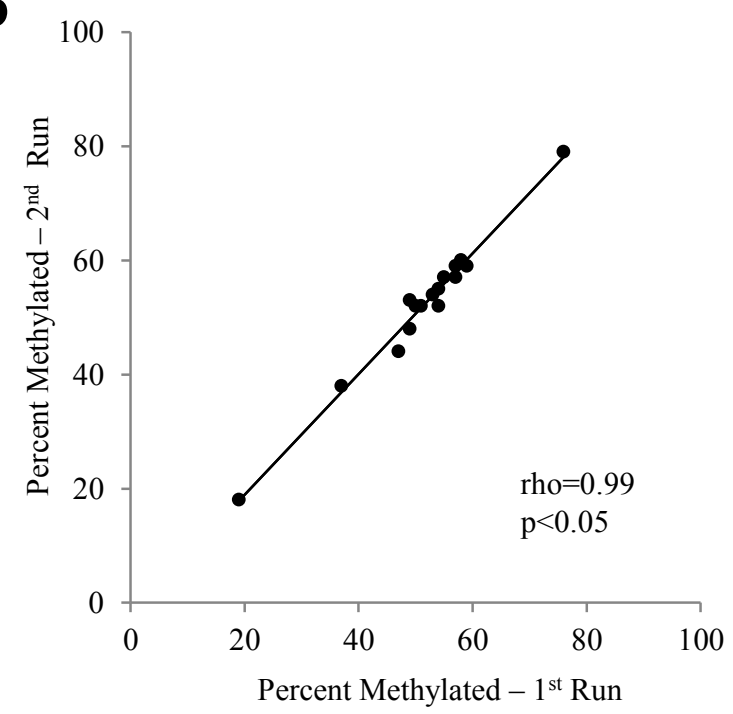

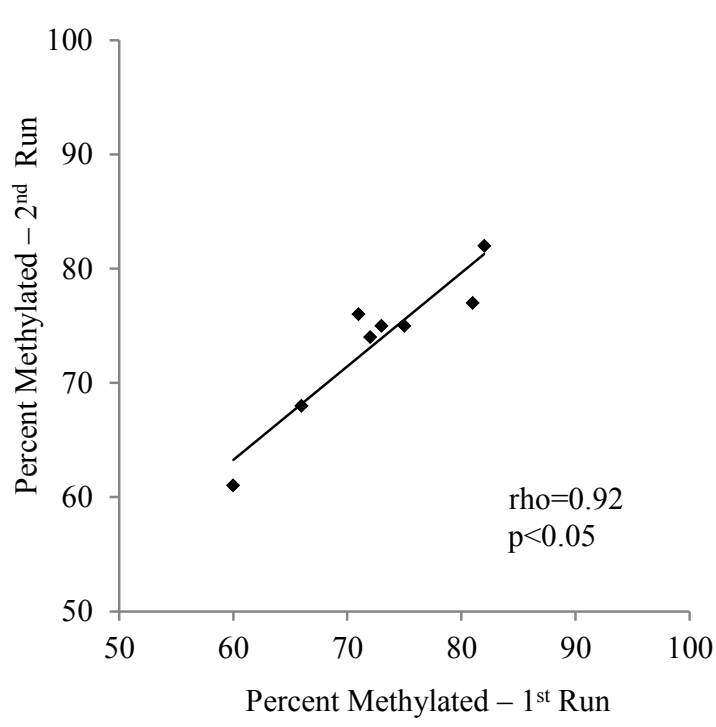



Figure 2 Concordance correlations between replicate samples for (a) $\mathrm{CpG}^{-186}$ (left, $\mathrm{n}=9$ ) and $\mathrm{CpG}^{-54}$ (right, $\mathrm{n}=8$ ) on interferon (IFN $\gamma$ ) proximal promoter; (b) $\mathrm{CpG}^{-359}$ (left, $\mathrm{n}=16$ ) and $\mathrm{CpG}^{-352}$ (right, $\mathrm{n}=14$ ) located in the inducible nitric oxide synthase (iNOS) proximal promoter. Samples represent repeat pyrosequencing runs of same sample of bisulfite converted DNA.

samples were $0.86(P<0.05)$ and $0.92(P<0.05)$ for $\mathrm{CpG}^{-186}$ and $\mathrm{CpG}^{-54}$, respectively; and for iNOS $0.98(P$ $<0.05)$ and $0.99(P<0.05)$ for $\mathrm{CpG}^{-359}$ and $\mathrm{CpG}^{-352}$, respectively. To determine the reproducibility of buccal cell samples collected from children in 'real world' conditions, field duplicate samples were collected. We also found a high correlation between duplicate samples for IFN $\gamma$ and iNOS at all CpG sites tested (Figure 3). Specifically, the concordance correlations (rho) for IFN $\gamma$ duplicate samples were $0.88(P<0.05)$ and $0.91(P<$ $0.05)$ for $\mathrm{CpG}^{-186}$ and $\mathrm{CpG}^{-54}$, respectively; and $0.83(P$ $<0.05)$ and $0.88(P<0.05)$ for iNOS duplicate samples $\mathrm{CpG}^{-359}$ and $\mathrm{CpG}^{-352}$, respectively. In addition, the methylation levels of the two iNOS CpG sites correlated highly with each other (Spearman $\mathrm{r}=0.77, P<0.05, \mathrm{n}$ $=28$ ), whereas the two IFN $\gamma$ CpG sites correlated only moderately with each other $(\mathrm{r}=0.45, P<0.05, \mathrm{n}=20)$. Neither iNOS CpG site correlated with either IFN $\gamma$ site.

To address a basic question about the time course of DNA methylation, we asked whether buccal cell methylation levels would vary when remeasured days later. We found that repeat samples for iNOS and IFN $\gamma$ collected 4 to 7 days later demonstrated low within-subject correlations (Figure 4). For example, the within-subject correlations for IFN $\gamma$ repeat samples were: $\mathrm{r}=0.56(P=$ $0.06)$ and $0.23(P=0.26)$ for $\mathrm{CpG}^{-186}$ and $\mathrm{CpG}^{-54}$, 
$\mathbf{a}$

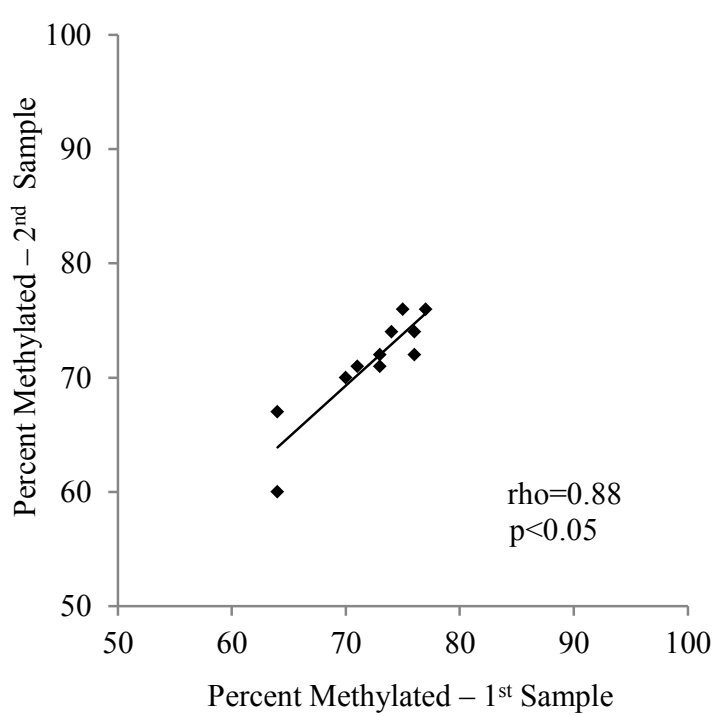

b



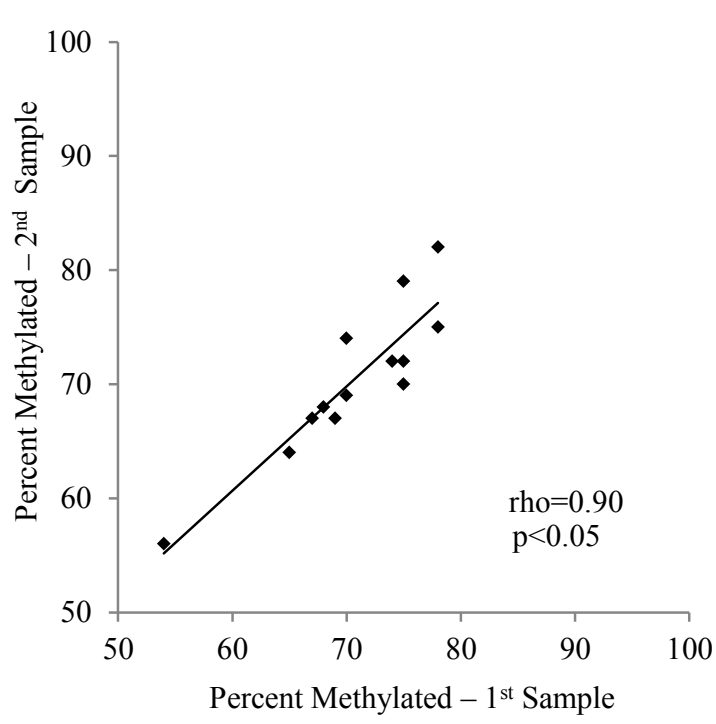

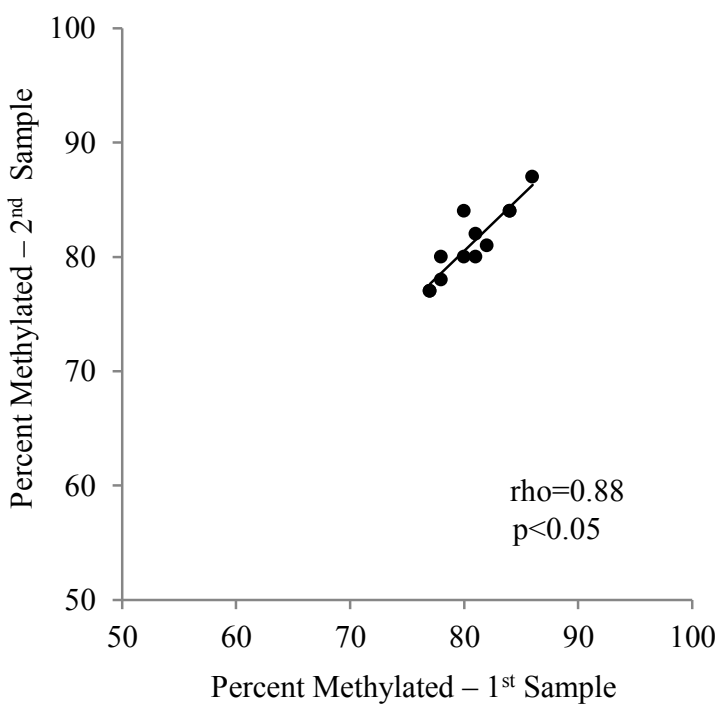

Figure 3 Concordance correlations between duplicate samples for (a) $\mathrm{CpG}^{-186}$ (left, $\mathrm{n}=11$ ) and $\mathrm{CpG}^{-54}$ (right, $\mathrm{n}=13$ ) on interferon (IFN $\gamma$ ) proximal promoter; (b) $\mathrm{CpG}^{-359}$ (left, $\mathrm{n}=11$ ) and $\mathrm{CpG}^{-352}$ (right, $\mathrm{n}=10$ ) located in the inducible nitric oxide synthase (iNOS) proximal promoter proximal promoter. Samples were collected from sequential buccal swabs minutes apart.

respectively; and the within-subject correlations for iNOS repeat samples were: $\mathrm{r}=0.20(P=0.29)$ and 0.19 $(P=0.30)$ for $\mathrm{CpG}^{-359}$ and $\mathrm{CpG}^{-352}$, respectively. These results suggest that DNA methylation levels vary over a 4 to 7 day period within individual subjects.

\section{Discussion}

Our first objective was to assess the reproducibility of buccal DNA collection and quantification of DNA methylation of asthma genes among a cohort of young children. We found that replicate and field duplicate samples correlated strongly. These results suggest our field and laboratory procedures (including bisulfite conversion, pyrosequencing) are robust, and that collection and measure of buccal cell DNA methylation in cohort studies can have great utility. Also they allow us to start answering fundamental questions about the stability of DNA methylation in buccal cells over time, questions that have significant implications for the understanding of environmental epigenetic regulation in children.

Upon confirming the feasibility and reproducibility of these measures, our next step was to assess acute differences in levels of buccal cell DNA methylation of select sites on two asthma genes tested days apart. We found low within-subject correlations for both IFN $\gamma(\mathrm{r}=0.56$ 
$\mathbf{a}$

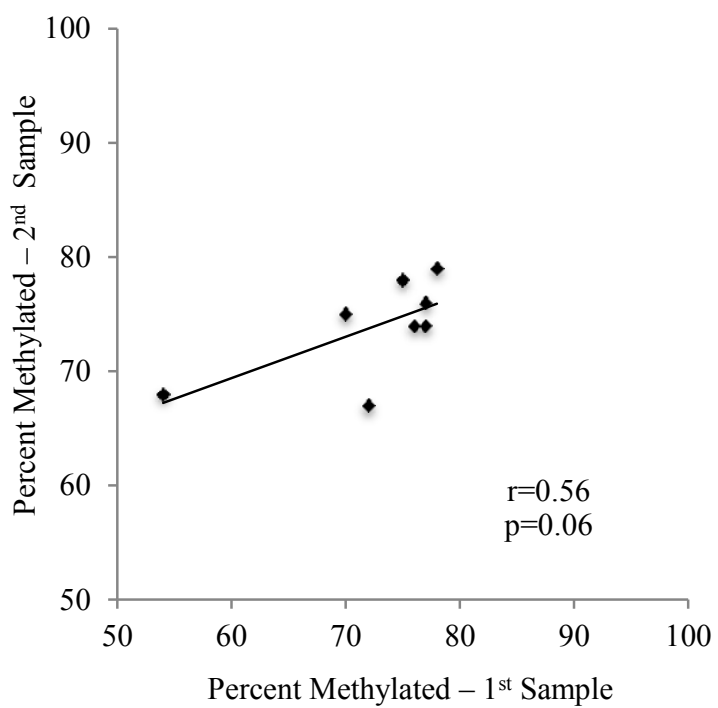

b

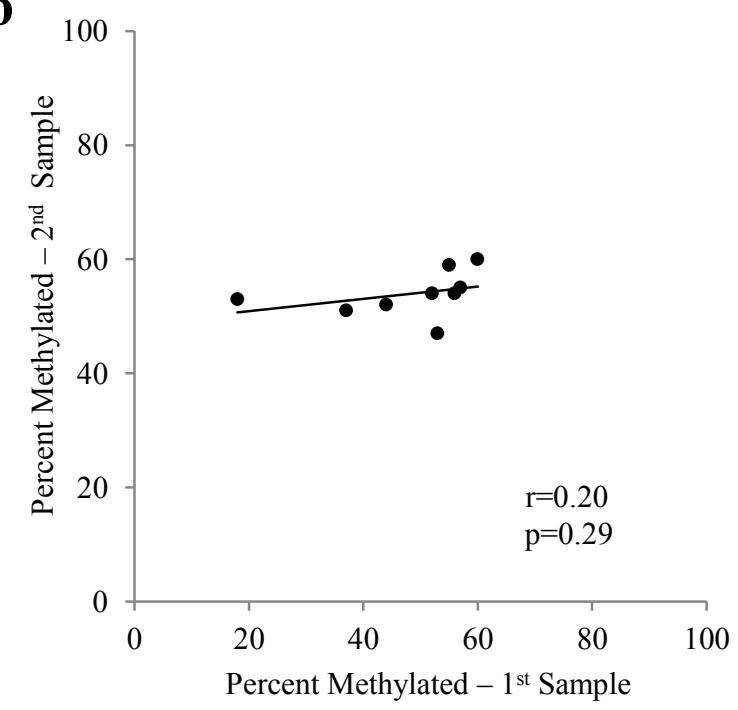

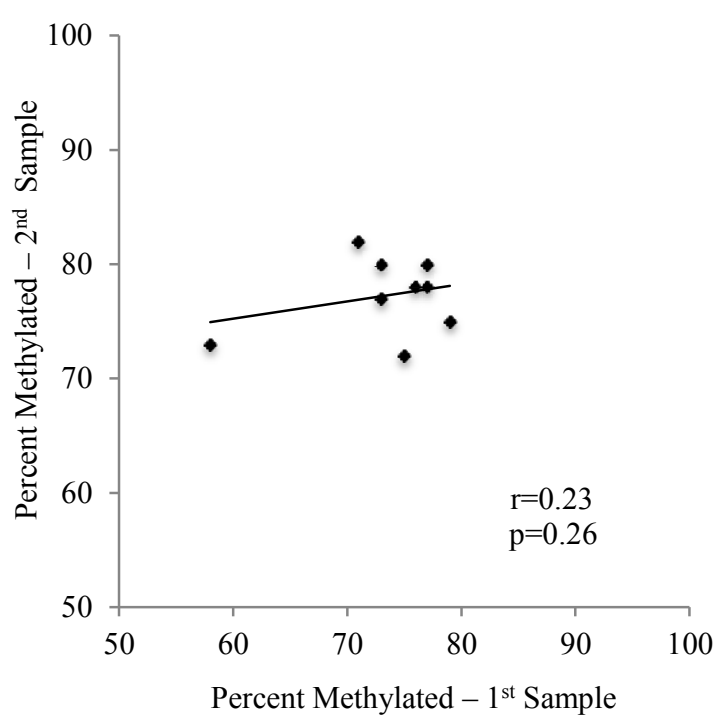

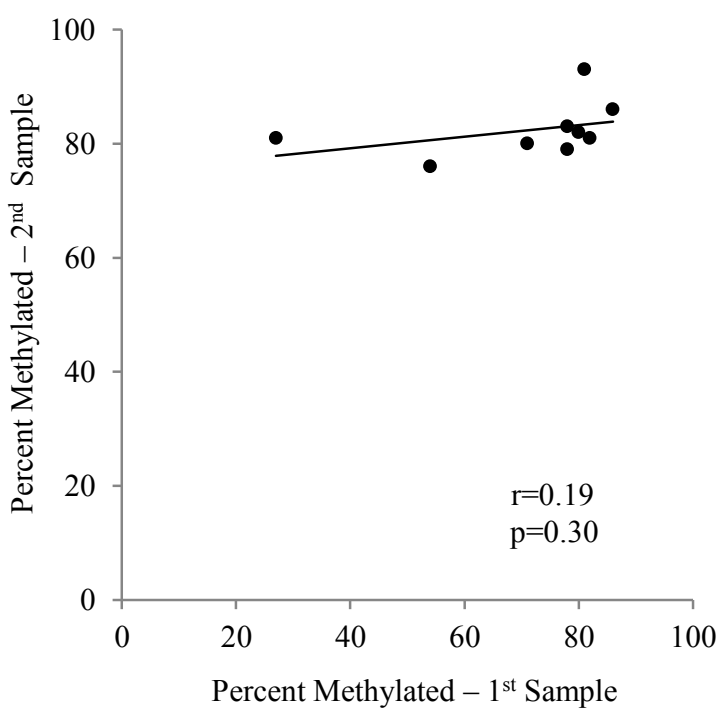

Figure 4 Within-subject correlations between samples repeated from same subjects 4 to 7 days apart, for (a) $\mathrm{CpG}^{-186}$ (left, $n=8$ ) and $\mathrm{CpG}^{-54}$ (right, $\mathrm{n}=9$ ) on the interferon (IFN $\gamma$ ) proximal promoter; (b) $\mathrm{CpG}^{-359}$ (left, $\mathrm{n}=9$ ) and $\mathrm{CpG}^{-352}$ (right, $\mathrm{n}=9$ ) on the inducible nitric oxide synthase (iNOS) proximal promoter.

and 0.23 for $\mathrm{CpG}^{-186}, \mathrm{CpG}^{-54}$, respectively) and iNOS (r $=0.20$ and 0.19 for $\mathrm{CpG}^{-359}, \mathrm{CpG}^{-352}$, respectively) upon repeat testing over a 4 to 7 day period. Combined with the high level of reproducibility previously demonstrated, these data suggest that methylation levels can change acutely in both genes. These findings are novel in that research measuring short-term changes in methylation has been limited, with only a few examples to date $[23,26]$. For example, Baccarelli and colleagues tested blood DNA methylation levels in long interspersed nucleotide elements (LINE 1) and Alu element (Alu) as surrogates of global methylation levels after acute exposure to black carbon/soot. They found an association between ambient black carbon levels and LINE 1, but not Alu, demethylation suggesting that global epigenetic regulation may occur in association with measures of recent air pollution exposure. As a second example, Tarantini and colleagues, in addition to assessing acute changes in global methylation (LINE 1, Alu), assessed PBMC DNA methylation levels in the proinflammatory iNOS gene over a 3-day period. Interestingly, they found an association between concentrations of $\mathrm{PM}_{10}$ particles and iNOS demethylation, implicating this regulator of airway inflammation as a gene whose expression may depend in part on alteration of DNA methylation levels. 
We reasoned that genes expressed in buccal cells, like those in peripheral blood mononuclear cells, also could undergo acute changes in DNA methylation, presumably following recent changes in environmental triggers. Inducible NOS was a main focus of this investigation because of Tarantini's and colleagues' reports, and because of its reported expression in the buccal mucosa [27]. Interestingly, methylation levels and interquartile ranges observed in this study of inner city asthmatic children were strikingly similar to the report by Breton and colleagues in a Southern California cohort, suggesting that some of our new results may be generalizable to other cohorts.

The second main focus, namely susceptibility of buccal cells to undergo DNA methylation in the promoter region of IFN $\gamma$, was in response to considerable previous work that suggests methylation of IFN $\gamma$ is critical to its gene expression $[15,28]$. This body of work also includes our previous findings in mice that CD4+ $\mathrm{T}$ cells undergo increases in IFN $\gamma$ DNA methylation in multiple CpG sites following exposures to diesel exhaust particles. In these experiments, methylation levels were measured once after 3 weeks of diesel exposure. The hypermethylation that occurred over this period was suspected to induce silencing of the IFN $\gamma$ gene and downregulation of the production of proallergic IgE antibodies, as indicated by the observed inverse correlation between IFN $\gamma$ methylation levels and IgE [13]. Indeed the $\mathrm{CpG}$ sites studied here $\left(\mathrm{CpG}^{-186}\right.$ and $\left.\mathrm{CpG}^{-54}\right)$ are conserved in mice [28]. One of the few studies of human cells to date, conducted by Gonsky and colleagues, looked at the same loci in the promoter of IFN $\gamma$ $\left(\mathrm{CpG}^{-186}\right.$ and $\left.\mathrm{CpG}^{-54}\right)$ in lamina propria $\mathrm{T}$ cells and peripheral blood T cells [29]. Their group found that a 5\% reduction in methylation of $\mathrm{CpG}^{-54}$ in the promoter region of IFN $\gamma$ was associated with a threefold increase in IFN $\gamma$ gene expression. While our study did not link the changes in IFN $\gamma$ promoter methylation in buccal cells over time with downstream biological events as the Liu et al. and Gonsky et al. studies did, it does for the first time show that the time course for changes in DNA methylation can be as short as several days in a pediatric cohort.

We acknowledge several limitations to the study. First, a limited number of asthma genes, and $\mathrm{CpG}$ sites per gene, were studied. Examination of additional CpG sites and asthma genes may help elucidate the time course of epigenetic change of other genes important to airway inflammation. To date it still needs to be ascertained how methylation levels across multiple CpG sites may impact gene transcription differentially, though early evidence suggests that particular sites, such as in proximal gene promoters such as IFN $\gamma \mathrm{CpG}^{-54}$, may be critical [28]. Alternately, other evidence suggests that CpG methylation in the intron could affect elongation and thereby gene transcription [30,31]. Also, the sample size was small, though sufficient to evaluate the quality of the reproduced data. The data display ranges of methylation that may be shown to be biologically meaningful in future studies. The buccal cell collection does not test for cell specific effects nor necessarily represent what occurs in respiratory epithelium. The magnitude of changes may vary across tissues. Moreover, in the absence of corresponding gene expression data, it may be difficult to know whether their epigenetic changes led to downstream molecular events. Repeat findings in other cohorts would be helpful to validate these results.

\section{Conclusions}

In summary, these findings suggest that buccal sampling is a feasible, non-invasive technique that yields reproducible results. The low correlations found during repeat sampling, especially when contrasted with highly correlated replicate and duplicate samples, suggest that changes in the level of DNA methylation can occur acutely, over a 4 to 7 day period. Given the dynamism of these epigenetic marks, one could speculate that these epigenetic marks are responsive to the rapidly changing environmental exposures. Asthma is a complex environmentally related disease with a rising US childhood prevalence of $9.4 \%$ [32], reaching as high as $28.5 \%$ in some areas of New York City [33]. By 2025, asthma is estimated to affect over 100 million people worldwide [34]. Understanding the triggers for asthma exacerbations and their associated molecular immune responses requires longitudinal studies that carefully pair environmental measures with relevant epigenetic biomarkers and clinical outcomes. These results suggest that such work can be conducted safely and accurately in an inner city pediatric cohort through buccal cell sampling and pyrosequencing of asthma genes.

\section{Acknowledgements}

Funding sources: US National Institute of Health grants R01ES13163, P50 ES015905, and P30ES09089.

\section{Author details \\ ${ }^{1}$ Division of Pulmonary, Allergy and Critical Care of Medicine, PH8E, \\ Columbia University Medical Center, 630 West 168th Street, New York, NY 10032, USA. ²Department of Environmental Health Sciences, Mailman School of Public Health, Columbia University, 722 West 168th Street, New York, NY 10032, USA. ${ }^{3}$ Department of Pediatrics, Columbia University Medical Center, PH8E, 630 West 168th Street, New York, NY 10032, USA.}

\section{Authors' contributions}

DZT participated in the design and coordination of the study, and drafted the manuscript. JSK participated in the conduction and coordination of the study, its statistical analysis and edited the manuscript. KM participated in the conduction of the study, and edited the manuscript. HJ participated in the conduction of the study and edited the manuscript. MMN participated in the conduction of the study and edited the manuscript. FPP participated in the study design and edited the manuscript. RLM designed and 
coordinated the study, participated in the statistical analysis, and drafted the manuscript. All authors read and approved the final manuscript.

\section{Competing interests}

The authors declare that they have no competing interests.

Received: 19 July 2011 Accepted: 1 February 2012

Published: 1 February 2012

\section{References}

1. Patel MM, Hoepner L, Garfinkel R, Chillrud S, Reyes A, Quinn JW, Perera F, Miller RL: Ambient metals, elemental carbon, and wheeze and cough in New York City children through 24 months of age. Am J Respir Crit Care Med 2009, 180:1107-1113.

2. Patel MM, Miller RL: Air pollution and childhood asthma: recent advances and future directions. Curr Opin Pediatr 2009, 21:235-242.

3. Romieu I, Barraza-Villarreal A, Escamilla-Nun C, Almstrand AC, Diaz Sanchez D, Sly PD, Olin AC: Exhaled breath malondialdehyde as a marker of effect of exposure to air pollution in children with asthma. J Allergy Clin Immunol 2008, 121:903-909.

4. Gilliland FD, McConnell R, Peters J, Gong H Jr: A theoretical basis for investigating ambient air pollution and children's respiratory health. Environ Health Perspect 1999, 107(Suppl 3):403-407.

5. Liu L, Poon R, Chen L, Frescura AM, Montuschi P, Ciabattoni G, Wheeler A, Dales R: Acute effects of air pollution on pulmonary function, airway inflammation, and oxidative stress in asthmatic children. Environ Health Perspect 2009, 117:668-674.

6. Riedel M, Diaz-Sanchez D: Biology of diesel exhaust effects on respiratory function. J Allergy Clin Immunol 2005, 115:221-228.

7. Diaz-Sanchez D, Garcia MP, Wang M, Jyrala M, Saxon A: Nasal challenge with diesel exhaust particles can induce sensitization to a neoallergen in the human mucosa. J Allergy Clin Immunol 1999, 104:1183-1188.

8. Diaz-Sanchez D, Proietti L, Polosa R: Diesel fumes and the rising prevalence of atopy: an urban legend? Curr Allergy Asthma Rep 2003, 3:146-152.

9. Bateson TF, Schwartz J: Children's response to air pollutants. J Toxicol Environ Health A 2008, 71:238-243.

10. Miller RL, Ho SM: Environmental epigenetics and asthma: current concepts and call for studies. Am J Respir Crit Care Med 2008, 177:567-573.

11. Kuriakose JS, Miller RL: Environmental epigenetics and allergic diseases: recent advances. Clin Exp Allergy 2010, 40:1602-1610.

12. Perera F, Tang WY, Herbstman J, Tang D, Levin L, Miller R, Ho SM: Relation of DNA methylation of 5 '-CpG island of ACSL3 to transplacental exposure to airborne polycyclic aromatic hydrocarbons and childhood asthma. PLOS ONE 2009, 4:e4488.

13. Liu J, Ballaney M, Al-alem U, Ouan C, Jin X, Perera F, Chen LC, Miller RL: Combined inhaled diesel exhaust particles and allergen exposure alter methylation of $\mathrm{T}$ helper genes and IgE production in vivo. Toxicol $\mathrm{Sci}$ 2008, 102:76-81.

14. Cao D, Bromberg PA, Samet JM: COX-2 expression induced by diesel particles involves chromatin modification and degradation of HDAC1. Am J Respir Cell Mol Biol 2007, 37:232-239.

15. White GP, Hollams EM, Yerkovich ST, Bosco A, Holt BJ, Bassami MR, Kusel M, Sly PD, Holt PG: CpG methylation patterns in IFNy promoter in naive $T$ cells: variations during Th1 and Th2 differentiation and between atopics and non-atopics. Pediatr Allergy Immu 2006, 17:557-564.

16. Kwon NH, Kim JS, Lee JY, Oh MJ, Choi DC: DNA methylation and the expression of IL-4 and IFN- $\gamma$ promoter genes in patients with bronchial asthma. J Clin Immunol 2008, 28:139-146.

17. Breton CV, Byun HM, Wang X, Salam MT, Siegmund K, Gilliland FD: DNA methylation in the ARG-NOS pathway is associated with exhaled nitric oxide in asthmatic children. Am J Respir Crit Care Med 2011, 184:191-197.

18. Sridhar S, Schembri F, Zeskind J, Shah V, Gustafson AM, Steiling K, Liu G, Dumas YM, Zhang X, Brody JS, Lenburg ME, Spira A: Smoking-induced gene expression changes in the bronchial airways are reflected in nasal and buccal epithelium. BMC Genom 2008, 9:259.

19. Johanning GL, Heimburger DC, Piyathilake CJ: DNA methylation and diet in cancer. J Nutrition 2002, 132:3814S-3818S

20. Bhutani M, Pathak AK, Fan YH, Liu DD, Lee JJ, Tang H, Kurie JM, Morice RC, Kim ES, Hong WK, Mao L: Oral epithelium as a surrogate tissue for assessing smoking-induced molecular alterations in the lungs. Cancer Prev Res 2009, 1:39-44

21. Moseley PL, Hemken C, Monick MM, Nugent KM, Hunninghake GW: Interferon and growth factor activity for human lung fibroblasts: release from bronchoalveolar cells from patients with active sarcoidosis. Chest 1986, 89:657-662.

22. Schoenborn JR, Dorschner M, Sekimata M, Santer DM, Shnyreva M, Fitzpatrick DR, Stamatoyannopoulos JA, Wilson CB: Comprehensive epigenetic profiling identifies multiple distal regulatory elements directing IFN- $\gamma$ transcription. Nat Immunol 2007, 8:732-742

23. Tarantini L, Bonzini M, Apostoli $P$, Pegoraro V, Bollati $V$, Marinelli $B$, Cantone L, Rizzo G, Hou L, Schwartz J, Bertazzi PA, Baccarelli A: Effects of particulate matter on genomic DNA methylation content and iNOS promoter methylation. Environ Health Perspect 2009, 117:217-222.

24. Perera FP, Rauh V, Tsai WY, Kinney P, Camann D, Barr D, Bernert T, Garfinkel R, Tu YH, Diaz D, Dietrich J, Whyatt RM: Effects of transplacental exposure to environmental pollutants on birth outcomes in a multiethnic population. Environ Health Perspect 2003, 111:201-205.

25. Whyatt RM, Barr DB, Camann DE, Kinney PL, Barr JR, Andrews HF, Hoepner LA, Garfinkel R, Hazi Y, Reyes A, Ramirez J, Cosme Y, Perera FP. Contemporary-use pesticides in personal air samples during pregnancy and blood samples at delivery among urban minority mothers and newborns. Environ Health Perspect 2003, 111:749-756.

26. Baccarelli A, Wright RO, Bollati $V$, Tarantini L, Litonjua AA, Suh $H H$, Zanobetti A, Sparrow D, Vokonas PS, Schwartz J: Rapid DNA methylation changes after exposure to traffic particles. Am J Respir Crit Care Med 2009, 179:572-578.

27. Arany I, Brysk MM, Brysk H, Tyring SK: Regulation of inducible nitric oxide synthase mRNA levels by differentiation and cytokines in human keratinocytes. Biochem Biophys Res Commun 1996, 220:618-622.

28. Jones B, Chen J: Inhibition of IFN- $\gamma$ transcription by site-specific methylation during T helper cell development. EMBO J 2006, 25:2443-2452.

29. Gonsky R, Deem RL, Targan SR: Distinct methylation of IFNY in the gut. $J$ Interferon Cytokine Res 2009, 29:407-414.

30. Lorincz MC, Dickerson DR, Schmitt M, Groudine M: Intragenic DNA methylation alters chromatin structure and elongation efficiency in mammalian cells. Nat Struct Mol Biol 2004, 11:1068-1075.

31. Klose RJ, Bird AP: Genomic DNA methylation: the mark and its mediators. Trends Biochem Sci 2006, 31:89-97.

32. Centers for Disease Control and Prevention: Asthma Factsheet.[http://www. cdc.gov/nchs/fastats/asthma.htm]

33. Nicholas SW, Jean-Louis B, Ortiz B, Northridge M, Shoemaker K, Vaughan R, Rome M, Canada G, Hutchinson V: Addressing the childhood asthma crisis in Harlem: the Harlem Children's Zone Asthma Initiative. Am J Public Health 2005, 95:245-249.

34. World Health Organization: Global surveillance, prevention and control of chronic respiratory diseases: a comprehensive approach., http://www. who.int/gard/publications/GARD Book 2007.pdf.

doi:10.1186/1868-7083-4-3

Cite this article as: Torrone et al:: Reproducibility and intraindividual variation over days in buccal cell DNA methylation of two asthma genes, interferon $\gamma$ (IFN $\gamma$ ) and inducible nitric oxide synthase (iNOS). Clinical Epigenetics 2012 4:3.

\section{Submit your next manuscript to BioMed Central and take full advantage of:}

- Convenient online submission

- Thorough peer review

- No space constraints or color figure charges

- Immediate publication on acceptance

- Inclusion in PubMed, CAS, Scopus and Google Scholar

- Research which is freely available for redistribution 